\title{
IMPLEMENTATION OF INDEPENDENT LEARNING TO INCREASE PRODUCTIVITY AND STUDENTS LEARNING OUTCOMES DURING THE COVID-19 PANDEMIC
}

\author{
Oleh \\ I Ketut Sudarsana \\ Universitas Hindu Negeri I Gusti Bagus Sugriwa Denpasar \\ iketutsudarsana@uhnsugriwa.ac.id
}

\begin{abstract}
Abstrak
Tujuan penelitian ini untuk mengetahui sejauh mana peningkatan produktivitas dan nilai belajar mahasiswa di tengah pandemi COVID-19 melalui implementasi pembelajaran mandiri. Penerapan model pembelajaran mandiri ini didasari dengan adanya himbauan serta kebijakan pemerintah yang mengharuskan serta mewajibkan dosen dan mahasiswa melakukan proses pembelajaran dirumah masing-masing. Subjek utama penelitian ini yakni seluruh mahasiswa semester I Kelas A Program Studi Pendidikan Agama Hindu Fakultas Dharma Acarya Universitas Hindu Negeri I Gusti Bagus Sugriwa Denpasar dengan jumlah 28 Orang. Dari hasil penelitian menunjukan 98\% mahasiswa mengalami peningkatan produktivitas belajar yang didukung dengan adanya peningkatan hasil belajar dengan persentase 96\%. Peningkatan ini dibuktikan dengan membandingkan nilai UTS dengan nilai UAS. Peningkatan nilai belajar mahasiswa ini tidak lepas dari dukungan orangtua, pengawasan dosen serta program pembelajaran daring menggunakan zoom. Selain itu program pembelajaran berbantukan youtube juga merupakan salah satu penunjang implementasi pembelajaran mandiri, disamping buku-buku pembelajaran yang diperoleh secara online. Model pembelajaran mandiri ini dirasa produktif diterapkan ditengah pandemi COVID-19 ini guna mendukung kebijakan pemerintah dalam melakukan social distantancing sekaligus untuk meningkatkan produktivitas belajar mahasiswa.

Kata Kunci: Pembelajaran Mandiri; Produktivitas Belajar; Hasil Belajar.
\end{abstract}

\section{Abstract}

The study aimed to determine the extent of the productivity and students' learning outcomes increased during the COVID-19 pandemic through the independent learning implementation. The implementation of this independent learning model is based on the existence of appeals and government policies that require and oblige lecturers and students to carry out the learning process at their respective homes. The main subjects of this study were all students in the first semester of Class $A$ of the Hindu Religious Education Study Program, Faculty of Dharma Acarya, Universitas Hindu Negeri I Gusti Bagus Sugriwa Denpasar with a total of 28 people. The results showed that $98 \%$ of students experienced an increase in learning productivity. It was supported by an increase in learning outcomes with

Implementation Of Independent Learning To Increase Productivity And Students Learning Outcomes During The Covid-19 Pandemic 
a percentage of $96 \%$. This increase was evidenced by comparing the middle test score with the final test score. The increase in student learning outcomes cannot be separated from parents' support, supervision of lecturers, and online learning programs using zoom. The YouTube-assisted learning program is also a way to support the independent learning implementation, besides learning books obtained online. This independent learning model is considered productive during the COVID-19 pandemic to support government policy in conduct social distancing and increasing student learning productivity.

Keywords: Independent Learning; Learning Productivity; Learning Outcomes

\section{PENDAHULUAN}

Currently, Indonesia and even several countries in the world are fighting against COVID-19. This pandemic has become a serious concern that causes President Joko Widodo to issue several policies as well as appeal to all levels of Indonesian society to conduct social distancing. The Indonesian government has pursued various policies to increase vigilance, especially in especially in preventing term the spread of cases, including starts from implementing a work and study from home policy to proposing large-scale social restrictions (PSBB) (Yulianingsih, Suhanadji, Nugroho \& Mustakim, 2020). This situation requires, obliges, and forces the community to reduce activities outside the home, which at the same time have a big impact on the world of education. The significant impact that occurs is the implementation of an online learning process or learning at home. This appeal to study at home resulted in all lecturers having to change their learning model inevitably.

According to Suhandi \& Pamela (2020), this outbreak has a huge impact on various aspects of life in Indonesia, especially in terms of education. Because the positive number of Covid-19 continues to increase every day, the government finally issued a policy to have a holiday from learning activities at school. The learning will be carried out at home until an undetermined time limit. In this case, teaching and learning activities are carried out by applying the online method. At first, there were many obstacles when carrying out learning activities with this online method. It because not all children and parents have smartphones or long-distance communication devices and their economic backgrounds also differ. Then, it may be more difficult in remote areas because there is no internet access.

Based on various obstacles that occur above, it is necessary to have an appropriate learning approach strategy to overcome the learning material achievement and competencies in accordance with the expected objectives. The learning strategy used adjusted to government policy through ministerial regulations based on national education standards. It includes content standards and an independent learning process. Implementation of this learning is applied by several educators in Indonesia. Several types of learning models have been applied to support the successful learning process of students, especially independent learning. According to Putra (2017), independent learning is a learning strategy carried out individually or in groups outside of face-to-face learning or tutorials. Independent learning needs to be well managed by tutors and managers, through a careful planning

Implementation Of Independent Learning To Increase Productivity And Students Learning Outcomes During The Covid-19 Pandemic 
process. The implementation of independent learning refers to the mature preparation stage, coordinated implementation, and an accurate outcome assessment process, thus the community can achieve the expected competency standards.

The Hindu Religious Education Study Program, Faculty of Dharma Acarya, Universitas Hindu Negeri I Gusti Bagus Sugriwa Denpasar also participated in supporting the government policies. The independent learning model is a type of learning model that provides the widest space for students to determine their learning strategies and provides opportunities for students to innovate in their learning development. The implementation of the independent learning model carried out by students of the Hindu Religious Education Study Program has a positive impact because students can independently learn according to their wishes and interests without any pressure. As it is known that the first semester students are new students who have an average age ranging from 17-18 years. This age is still relatively early adolescence, so it is good if you are forced to study hard.

The implementation of the selflearning model during the COVID-19 pandemic is one of the right choices to apply. Online learning activities like this require students to be independent in learning. Independent learning (Self-Regulated Learning) is required by students in building the concepts and principles they learn. Independent learning is a self-awareness to learn without depending on others and feel responsible for achieving the desired goals (Hamka, D. \& Vilmala, B.K., 2019). With this independent learning model, student learning productivity will increase due to government support by broadcasting online learning programs.

This learning program is one of the major supports in the application of the independent learning model besides support from parents and books that are widely available on the internet. In the application of this independent learning model, a lecturer acts as a facilitator and a supervisor who supervises and helps students who need assistance. According to Ranti, Budiarti \& Trisna (2017), when the learning process does not emphasize the aspects of independent learning, it indicates that the independent learning aspect has not been considered an important factor that affects student learning outcomes, even though there is a tendency where the higher the level of education, the independent learning that is required getting higher too.

The form of assistance provided by the lecturer is in the form of explanations related to the material being asked by students. Besides being a facilitator, lecturers occasionally provide evaluations related to independent learning carried out by students. The evaluation is given in the form of an enrichment task. After giving assignments, the lecturer will give time for students to work on these assignments. After the assignment is completed, the lecturer can assess the student's answers, which at the same time the lecturer can assess the extent to which the productivity of the application of independent learning is being implemented during the COVID-19 pandemic. Research is important to find out the percentage increase in productivity and student learning outcomes.

Research conducted during the COVID-19 pandemic uses a method of comparing the previous score results with the

Implementation Of Independent Learning To Increase Productivity And Students Learning Outcomes During The Covid-19 Pandemic Universitas Hindu Negeri I Gusti Bagus Sugriwa 
assignment results during the implementation of this independent learning model. The application of the independent learning model this time is slightly different from the adult independent learning method. In general, independent learning is self-study, selfunderstanding, and evaluating their abilities. The independent learning model applied by students of the Hindu Religious Education Study Program, Faculty of Dharma Acarya, Universitas Hindu Negeri I Gusti Bagus Sugriwa Denpasar has a characteristic that the lecturer is a facilitator and a person who plays an important role in assessing or evaluating student learning development. Students learn on their own using their ways or methods in understanding the basic competencies in the curriculum including the competency achievement indicators (GPA). In other words, students are given space to innovate in their learning process. Independent learning in their way, in a comfortable place, according to him and with his intentions and desires. Students are free to choose the person who will help them understand the assigned material.

This study aims to examine the development or productivity of students in independent learning during the COVID-19 pandemic. To examine the extent of students' learning outcomes have increased during this COVID-19 pandemic. It hopes that this study can help lecturers determine the appropriate and efficient learning strategy in the future.

\section{METHODS}

The main research subjects were all students in the first semester of Class A of the Hindu Religious Education Study Program, Faculty of Dharma Acarya, Universitas Hindu Negeri I Gusti Bagus Sugriwa Denpasar with a total of 28 people. The main research object was the value of increasing student learning and observing the increase in student learning productivity during the COVID-19 pandemic by applying the independent learning model.

The first action taken was to observe related to the learning currents phenomenon that occurs in the Hindu Religious Education Study Program, Faculty of Dharma Acarya, Universitas Hindu Negeri I Gusti Bagus Sugriwa Denpasar. The second stage was the preparation of steps or research methods. The method used was the quantitative method by assessing the application of the online learning process or learning from home due to the COVID-19 pandemic. After the assessment was carried out, it followed by determining the object and subject to be studied. Determine the subject and object that will be followed by data collection. The data obtained from the subject to be studied or observed. After collected data, it followed by data by data analysis and comparison. With the data analysis, the results obtained in the form of a percentage increase in productivity and student learning outcomes.

\section{RESULTS AND DISCUSSIONS}

Through observation, assessment, collection, and data analysis, the results obtained in the form of a percentage increase in student learning productivity and student productivity of $100 \%$. The increase in productivity is evidenced by direct assessment and observation with photo documentation as evidence that students are productive in selfstudy in their respective homes. From the analysis results, it can be stated that all students of the Hindu Religious Education Study Program, Faculty of Dharma Acarya, 
Hindu State, Universitas Hindu Negeri I Gusti Bagus Sugriwa Denpasar are productive.

The analysis results of student productivity can be seen in the following obtained data.

\section{Students Productivity}

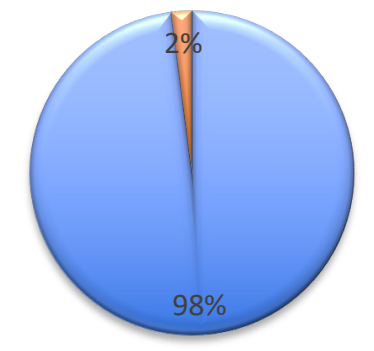

$\square$ Productive $\square$ Less Productive

Based on the student productivity diagram, it can be seen that $98 \%$ of students of the Hindu Religious Education Study Program, Faculty of Dharma Acarya, Universitas Hindu Negeri I Gusti Bagus Sugriwa Denpasar are productive, and only $2 \%$ are less productive.

As for students' learning outcomes can be seen in the diagram below.

\section{Student Learning Outcomes}

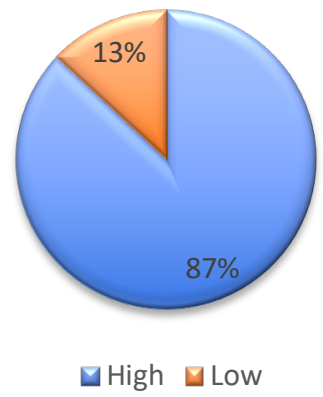

Based on the research results shown in the diagram above, it is found that $96 \%$ of students' learning outcomes of the Hindu Religious Education Study Program, Faculty of Dharma Acarya, Universitas Hindu Negeri I Gusti Bagus Sugriwa Denpasar are high and only $4 \%$ are low. Thus with the implementation of independent learning during the COVID-19 pandemic, it has been proven qualitatively to provide a significant increase in student productivity and student learning outcomes of the Hindu Religious Education Study Program, Faculty of Dharma Acarya, Universitas Hindu Negeri I Gusti Bagus Sugriwa Denpasar. The research results are in line with the research results by Misdalina, Ningsih \& Marhamah (2018) showing that there is a significant influence between independent learning on student learning outcomes.

Based on the research results that have been carried out, it can be conveyed that the implementation of independent learning during the COVID-19 pandemic is very effective. It is evidenced by the increase in student learning productivity and student learning outcomes. Likewise with Suhendri's research (2011) shows that the results are not much different, namely that independent learning has a positive effect on learning outcomes even though the results are not significant. Besides influences on learning outcomes, learning independence also has a positive influence on problem-solving abilities. It is shown by research conducted by Simanulang (2018) that independence and self-confidence have a positive and significant effect on improving problem-solving skills with a contribution of $68.7 \%$. The success of implementing this independent learning model is inseparable from the participation, support, and attention of parents towards their children's learning development. $98 \%$ of students are productive during this independent learning process. The lecturers' 
ability in online learning with the help of Zoom also influences student learning success. The use of Zoom application is inseparable from its advantages, such as (a) Unbuffered video calls, automatic adjustment, (b) Perfect audio calls and can be recorded for future review, (c) Conference calls, can easily present $10+$ parties without losing quality, (d) Screen sharing can be easily used and can choose a window or monitor to share, (e) Scheduling, it can easily schedule events and export to the calendar then invite guests (Komalasari, 2020). Besides parents, the learning video screening program that is broadcast on YouTube also has a major role and influence in the success of this independent learning model.

The independent learning model applied by students of the Hindu Religious Education Study Program, Faculty of Dharma Acarya, Universitas I Gusti Bagus Sugriwa Denpasar, has several differences. The difference refers to the standard of the applied learning concept. Independent learning is carried out to hone the academic (knowledge) and non-academic (self-potential) abilities of individuals who carry out this learning. Whereas in the concept of independent learning applied by the Hindu Religious Education Study Program, Faculty of Dharma Acarya, Universitas I Gusti Bagus Sugriwa Denpasar, lecturers have the space to choose and determine their own study time, learning resources, and learning styles. Things related to learning objectives are still held or determined by the lecturer.

Lecturers have the role of facilitators who help students if needed. Lecturers also have a great responsibility for the development and achievement of student learning outcomes. According to Kuswantoro
(Setiawan \& Komalasari, 2020), the disruption era is a challenge for educators that human roles are gradually being replaced by machines so that educators inevitably need to welcome this era by becoming disrupted educators. Development with innovation and renewal is important for educators to adapt. Educators emphasized studying a lot of literature both from books, journals, research results, and others that can add insight, thus their role cannot be replaced by anything. Thus, the development of educators' competencies needs to be carried out. With this independent learning, lecturers will occasionally monitor and evaluate the learning development of each student. From the observation results, an assessment is carried out to assess to what extent students can understand the learning material in references that have been previously given.

Through giving tests, students are allowed to do an evaluation test within one day. After collects the test, the lecturer will assess and evaluate to what extent students can answer in accordance with the questions of the test. Analyzing the evaluation results is the initial basis for determining the comparison of values before and after the independent learning model implementation.

As the final stage of this research, the percentage increase in student learning outcomes calculated. The results showed that $96 \%$ of students were able to improve their learning outcomes. Therefore, it can be said that the independent learning model implementation during the COVID-19 pandemic is very effective in increasing student productivity. It hopes that this research can help lecturers evaluate the use of learning models in the future. 


\section{CONCLUSIONS}

Based on the results of observations, assessments, data collection, data analysis, and data comparison, it can be concluded that the implementation of independent learning is a type of learning model that is considered to have high effectiveness if it is applied during the COVID-19 pandemic. By implementing this learning model, it is expected to increase student learning productivity in the learning process. Because students are given the widest possible opportunity to innovate in their learning. The results showed $98 \%$ of students experienced an increase in learning productivity which was supported by an increase in learning outcomes with a percentage of $96 \%$. The success of implementing this independent learning cannot be separated from the support of parents who always help lecturers to supervise, accompany, and shape their children who face learning difficulties. Besides the roles of parents, the learning program through YouTube is also very helpful in implementing this independent learning model. Therefore, the implementation of independent learning during the COVID-19 pandemic is very effective in the Hindu Religious Education Study Program, Faculty of Dharma Acarya, Universitas Hindu Negeri I Gusti Bagus Sugriwa Denpasar, and it shows very good results.

\section{REFERENCES}

Hamka, D. \& Vilmala, B.K. (2019). Pengembangan Perangkat Pembelajaran Blended Learning Melalui Aplikasi Google Classroom Untuk Peningkatan Kemandirian Belajar Mahasiswa. Journal of Education Informatic
Technology and Science (JeITS),1(2), 145-154.

Komalasari, R. (2020). Manfaat Teknologi Informasi dan Komunikasi di Masa Pandemi Covid 19. TEMATIK-Jurnal Teknologi Informasi Dan Komunikasi, 7(1), 38-50.

Misdalina, M., Ningsih, Y. L., \& Marhamah, M. (2018). Pengaruh Kemandirian Belajar Terhadap Hasil Belajar Mahasiswa. Jurnal Dosen Universitas PGRI Palembang.

Putra, R. A. (2017). Penerapan metode pembelajaran mandiri dalam meningkatkan hasil belajar peserta didik (studi pada program pendidikan kesetaraan paket c di PKBM bina mandiri cipageran). Jurnal Pendidikan Luar Sekolah, 13(1).

Ranti, M. G., Budiarti, I., \& Trisna, B. N. (2017). Pengaruh kemandirian belajar (self regulated learning) terhadap hasil belajar mahasiswa pada mata kuliah struktur aljabar. Math Didactic: Jurnal Pendidikan Matematika, 3(1), 75-83.

Setiawan, R., \& Komalasari, E. (2020). Membangun Efektifitas Pembelajaran Sosiologi Di Tengah Pandemi Covid19. EDUSOCIUS; Jurnal Ilmiah Penelitian Pendidikan dan Sosiologi, 4(1), 1-13.

Simanullang, B. (2018). Mengembangkan kemandirian belajar, kepercayaan diri, dan pengaruhnya terhadap Kemampuan pemecahan masalah matematika. Ejournal Widya Eksakta, 1(1), 62-69.

Suhandi, A., \& Pamela, I. S. (2020). Dampak Musim Libur Covid-19 Belajar dari Rumah Terhadap Psikologi Anak Sekolah Dasar. Jurnal Gentala Pendidikan Dasar, 5(2), 207-218. 
Suhendri, H. (2011). Pengaruh kecerdasan matematis-logis dan kemandirian belajar terhadap hasil belajar matematika. Formatif: Jurnal Ilmiah Pendidikan MIPA, 1(1).

Yulianingsih, W., Suhanadji, S., Nugroho, R., \& Mustakim, M. (2020). Keterlibatan Orangtua dalam Pendampingan Belajar Anak selama Masa Pandemi Covid-19. Jurnal Obsesi: Jurnal Pendidikan Anak Usia Dini, 5(2), 1138-1150 